in miformly eltaline: he, however, describes all the excretions in cholers as alkaline, and gives as the cause the ascertained presence of carbonate of ammonia, a circumstance to which he appears to me to attribute undue importance. This alkaline reaction, except in the case of the stools, is quite opposed to my own observations.

[To be continued.]

Crichton Royal Institution, Dumfries, A pril 1854.

\section{ATMOSPHERIC CHANGES RELATING TO THE PREVALENCE OF CHOLERA.}

\section{B̈ J. A. HINGESTON, Esq.}

Tine state of the weather during the recent outbreak of the cholera at Leeds, Dublin, and Glasgow, may be shown by the following table.

On comparing my report of the thermometer with that of Mr. Glaisher's, of Lewisham, I find that my arerage is below his in the spring of the year, and above his in the autumn. This difference is in all probability owing to the proximity of the ocean, - the surface of which is warmer than the atmosphere in the autumn, but colder in the spring. But most likely my means of observation are not so well appointed as his, in this respect. The mortality from ordinary causes was, at this time, quoted as being sixty below the average. There was a very still state. of the atmosphere, which was dark, misty, and on one day smelling disagreeably. There was a high barometer, although the air was loaded with vapour. Out of twentyfour cases of Asiatic cholera reported at Leeds, there were thirteen deaths.

This state of the atmosphere is so invariably attendant on the outbreak of cholern, that it may be regarded as a necessary condition for the activity of the disease. It would be affirming too much, to say that it is its cause.

I observed one peculiarity at this time which seemed to me a farourable omen, and such at least for the present it has shown itself to be. I allude to the lateritious sediment in the urine, which has prevailed a good deal lately. On former occasions, when the cholera has been rife, the urine has shown the predominance of the oxalic, or even the phosphatic diathesis; but on the present occasion it is just the reverse, the urea not appearing to be retained within the circulation. Its elimination is a sign of health, and contra-indicates the existence or duration of cholera.

Among the meteorological phenomeni, it is proper to mention the appearance of a comet on the border of Pisces, near to the star $\eta$ Andromeda, on Mirch 29 th.

Brighton, April, 1ris.

\begin{tabular}{|c|c|c|c|c|c|c|c|c|}
\hline 1054 & Wind. & Clouds. & Dew and rain. & Moisture. & Foree of wind. & 'Temperatiure. & Thermuzueter. & Barometer. \\
\hline Ma:ch $5 \ldots$ & N.E.S. & $\begin{array}{l}\text { Morning mist; } \\
\text { cloudless noon; }\end{array}$ & Dew. & $\begin{array}{l}\text { Noist; dry; } \\
\text { dusty; and }\end{array}$ & Calm. & Chilly. & $40-50$ & $\begin{array}{l}\text { Set fair ; } \\
\text { falling. }\end{array}$ \\
\hline $\begin{array}{c}\text { March } 6 \\
\text { (Moon .... }\end{array}$ & E.S.S.E. & $\begin{array}{l}\text { overcast. } \\
\text { Clear night; } \\
\text { morning mist; }\end{array}$ & & $\begin{array}{l}\text { clear. } \\
\text { Dry and } \\
\text { dusty. }\end{array}$ & Ditto. & $\begin{array}{l}\text { Cold ; } \\
\text { sharp } \\
\text { white frost ; }\end{array}$ & $25-15$ & $\begin{array}{l}\text { Ditto } \\
\text { t below. }\end{array}$ \\
\hline $\begin{array}{c}\text { first quarter, } \\
7 \text { p.M.) } \\
\text { March } 7 \text {.... }\end{array}$ & N.w.s. & $\begin{array}{l}\text { cloudess noon; } \\
\text { thick mist. } \\
\text { Dark mist; } \\
\text { bright strati ; }\end{array}$ & & $\begin{array}{l}\text { Moist; } \\
\text { thick. }\end{array}$ & Ditto. & $\begin{array}{l}\text { ice. } \\
\text { Ditto. }\end{array}$ & $20-.50$ & below. \\
\hline March $8 . .$. & w.s.w. & $\begin{array}{l}\text { dark mist. } \\
\text { Ditto ; ditto; } \\
\text { strati; }\end{array}$ & & Ditto. & $\begin{array}{c}\text { Ditto ; } \\
\text { light air s.w. }\end{array}$ & Ditto. & $45-57$ & Ditto. \\
\hline March $9 . .$. & w.s.w. & $\begin{array}{l}\text { dark mist. } \\
\text { Ditto; ditto; } \\
\text { ditto; ditto. }\end{array}$ & & $\begin{array}{l}\text { Moist fog, } \\
\text { smelling } \\
\text { disagreeably. }\end{array}$ & Ditto. & Raw cold. & $48-62$ & 3 below. \\
\hline March 10 .. & $\begin{array}{l}\text { w.s.w. } \\
\text { N.w. }\end{array}$ & $\begin{array}{l}\text { Overcast; } \\
\text { strati ; } \\
\text { cloudless } \\
\text { afternoon. }\end{array}$ & Light rain. & Wet fog. & $\begin{array}{l}\text { Wind rising } \\
\text { s.w.; } \\
\text { squally. }\end{array}$ & $\begin{array}{l}\text { Warmer, } \\
\text { but chilly. }\end{array}$ & $50-54$ & Fair. \\
\hline
\end{tabular}

\section{DISLOCATION OF BOTH HIPS AT THE SAME TIME IN THE SAME SUBJECT.}

\section{By H. L. PRICHARD, Esq}

Case I. Thomas Phillips, aged 15, a railway waggoner at the Cwmavon works, on the evening of the 25th of March, while in a stooping posture in the act of turning the switch, was overtaken and knocked down by a truck running with some velocity down an inclined plane. He escaped the wheels; but the body of the carriage, which was ten inches only from the ground, passed over him, and, as he described it, "doubled him up".

The case presented a remarkable appearance. The knees and toes were inverted; the former were closely approximating each other, while the latter rather overlapped one another. The head of each femur was distinctly felt under the glutæi, on the dorsum of the ilium.

The reduction of the right hip was readily effected with the pulleys, in the manner recommended by Sir Astley Cooper, with no other preparation than that of chloroform, which the patient took con amore. In eight or ten minutes the bone passed into its socket with a satisfactory jerk, audible to the byatanders. The left was immediately afterwards anjjected to the trestment in like manner, but was not 20 easily reduced. Extension having been kept up during thirty-five minutes, the knee was found to have descended parallel with that on the opposite side. The pulleys were relaxed, and the limb simultaneously rotated, while $\mathbf{m y}$ colleague, Mr. F. M. Russell, kept up the transverse extension in the usual manner, and the reduction was effected, but without a perceptible erack, - a ttributable, I apprehend, to the exhaustion of the muscles from continued extension.

I presume an accident of this description is very rare. It is the first with which I have met; and I do not recollect to have read of such a case.

As an addendum to the foregoing, I may be allowed to record a case which occurred in iny practice last evening (fourtcen days after the double dislocation), bearing out the singular coincidence in accidents, which, I doubt not, most of us of some years' experience must have observed.

Case 1I. Thomas Walters, aged 16, was run over by a train of coal trucks. When first seen, he was lying on his left side in bed. He complained of excruciating pain, referrible to his right hip and thigh. His knee was rather everted, and the foot inverted. Un examination, the knee was found to be shorter than the opposite one by an inch and a half; but the trochanter major was in its normal position, and no crepitus was discoverable. The tibia and fibula, however, above the malleoli were fractured. On 